\title{
DIVERSITY OF PREDACEOUS COCCINELLID BEETLES (COLEOPTERA: COCCINELLIDAE) IN UTTARAKHAND, NORTH INDIA
}

\author{
Ahmad Pervez ${ }^{1}$, Meena Yadav" and Moina Khan' \\ ${ }^{1}$ Biocontrol Laboratory, Department of Zoology, Radhey Hari Government Post Graduate College, \\ Kashipur, Udham Singh Nagar - 244713, Uttarakhand, India; \\ ${ }^{2}$ Department of Zoology, Maitreyi College, University of Delhi, New Delhi-110021, India
}

*Corresponding Author Email id: drmeena.yadav@gmail.com

Received: 19.08.2020; Revised: 22.9.2020; Accepted: 29.9.2020

(C)Society for Himalayan Action Research and Development

\begin{abstract}
A field survey was conducted to explore the diversity of predaceous ladybird beetles (Coleoptera: Coccinellidae) by sampling adults and larvae from five geographical habitats of Uttarakhand, North India. As a result, eighteen predaceous ladybird beetle species were identified belonging to 15 genera and 3 subfamilies: Chilocorinae, Coccinellinae, and Scymninae. These species were: Platynaspis saundersi, Adalia hexaspilota, Alloneda dodecaspilota, Calvia albida, Menochilus sexmaculatus, Coccinella septempunctata, Coccinella transversalis, Harmonia eucharis, Harmonia sedecimnotata; Hippodamia variegata, Illeis cincta, Illeis confusa, Micraspis discolor, Oenopia sauzeti, Propylea dissecta; Propylea luteopustulata; Palaeoneda auriculata and Scymnus posticalis. Of these, six species ladybird beetles are the first time reported from Uttarakhand. Their distinctive characters, distribution, host plant-prey range, active period, and ecological importance have been described. A few of these species may be potentially utilized as biological agents to control many phytophagous insect pests of agriculture and horticulture crops. A disparity was observed in the ladybird-abundance, as both the number of individuals of ladybirds and their frequency in the population differed significantly. The dominance of a few ladybird beetles, particularly $C$. septempunctata, M. sexmaculatus, $C$. transversalis and $H$. variegata was confirmed by the low value of Simpson's Dominance Index (0.1903) further indicating the disparity in the populations of different ladybird species in a community.
\end{abstract}

Keywords: Diversity, Coccinellidae, ladybird beetles, crops

\section{Introduction}

Majority of ladybird beetles (Coleoptera: Coccinellidae) are important group of biocontrol agents as they prey upon numerous phytophagous insect pests viz. aphids, mealy bugs, scale insects, whiteflies, thrips, and many more (Omkar and Pervez 2016; Pervez et al. 2020). Globally, more than 6000 ladybird beetle species are known; of which, 261 predaceous species are catalogued from India (Omkar and Pervez 2004). Family Coccinellidae branched into sub-families, viz. Chilocorine, Coccinellinae, Coccidulinae,
Ortalinae, Scymninae, Sticholotidinae and a phytophagous family Epilachninae (Bouchard et al. 2011). Indian ladybird diversity is highly enriched due to the large variations in the zoogeographical and climatic conditions. Uttarakhand is a North Indian state where the landscape has variations from mountains, hills, terrain, and plains. Previously, a few authors mentioned about the ladybird beetle diversity occurring in some particular regions of Uttarakhand, North India (Joshi and Sharma 2008; 
Sharma and Joshi 2010). More than 155 attempts have been made to manage aphid pests by introducing predaceous ladybird beetles (Joshi et al. 2003). The outcome of these attempts indicates their effectiveness. Thus, the diversity of these ladybirds from various zoogeographical habitats and their prey-range is important before manipulating them as biocontrol agents. Hence, an extensive survey was conducted in five geographical habitats of Uttarakhand, viz. Almora, Chamoli, Nainital, Udham Singh Nagar, and Uttarkashi to explore the biodiversity of predaceous ladybird beetles and their prey-range.

\section{Materials and Methods}

The extensive surveys were conducted from 01 September 2014 to 15 February, 2015 to collect the ladybirds from five geographical habitats of Uttarakhand (Almora, Chamoli, Nainital, Udham Singh Nagar and Uttarkashi) of various landscapes viz., mountain, hills, terai, and forests) (Table-1).

Table 1: Altitude and the geographical coordinates of the zoogeographical sites chosen for the survey.

\begin{tabular}{|l|l|l|l|}
\hline $\begin{array}{l}\text { Zoo- } \\
\text { geographical } \\
\text { Site }\end{array}$ & $\begin{array}{l}\text { Altitude } \\
(\mathbf{m})\end{array}$ & $\begin{array}{l}\text { Latitude } \\
(\mathbf{N})\end{array}$ & $\begin{array}{l}\text { Longitude } \\
(\mathbf{E})\end{array}$ \\
\hline $\begin{array}{l}\text { Udham Singh } \\
\text { Nagar }\end{array}$ & 217.93 & $30.2937^{\circ} \mathrm{N}$ & $79.5603^{\circ} \mathrm{E}$ \\
\hline Uttarkashi & 1157.94 & $30.7268^{\circ} \mathrm{N}$ & $78.4354^{\circ} \mathrm{E}$ \\
\hline Chamoli & 1402.08 & $30.0708^{\circ} \mathrm{N}$ & $79.5027^{\circ} \mathrm{E}$ \\
\hline Almora & 1861.11 & $29.5892^{\circ} \mathrm{N}$ & $79.6467^{\circ} \mathrm{E}$ \\
\hline Nainital & 2083.92 & $29.3803^{\circ} \mathrm{N}$ & $79.4636^{\circ} \mathrm{E}$ \\
\hline
\end{tabular}

The ladybird beetles present on herbaceous plants were collected using a standard entomological net and those present on different species of tree or shrub using a beating tray. "Sweep sampling Method”, as per O'Neill et al., (2003) and other methods, such as handpicking and aspiration were also used as per the plant morphology and the altitude of the habitat sampled. The collected ladybirds were taken to the laboratory. The adults of each species were carefully studied under a stereoscopic trinocular microscope (Lyzer at $40 \mathrm{X}$ magnification) to determine the scientific name of the species. Certain unidentified ladybirds were sent to Dr. J. Poorani, Scientist, National Bureau of Agricultural Insect Resources, Bengaluru560024, India for identification. The data on the number of individuals of a species and frequency of that species per 100 ladybirds were subjected to a one-sample t-test using ' 10 ' and ' 1 ', respectively as the other expected mean value to be compared using a statistical software MINITAB-13.0 on our personal computer.

Simpson's Dominance Index (C) was calculated using the modified following equation (1) of Thukral et al. (2019). C-value skewing towards zero indicates disparity and dominance of a few species over others, while that towards one indicates evenness amongst species and no disparity amongst number of individuals of a species in a community.

$$
C=\sum_{n=1}^{K} p_{i}^{2}
$$

Where $\mathrm{K}=$ number of species and $\mathrm{p}_{\mathrm{i}}$ is derived from the following equation (2)

$$
p_{i}=\frac{\text { Number of individuals of a species in a community }}{\text { Total number of individuals of all the species in a community }}
$$

\section{Results and Discussion}

Eighteen species from 15 genera belonging to the 3 subfamilies, Chilocorinae, Coccinellinae, and Scymninae and the single-family Coccinellidae were identified from various habitats and are presented in Table-2. Both the number of individuals of ladybirds $(\mathrm{t}=2.39 ; \mathrm{P}<0.05)$ and their frequency $(\mathrm{t}=2.17 ; \mathrm{P}<0.05)$ in the population were found to be statistically significant. This reveals a disparity in the number and frequency of different ladybird species in a particular zoo-geographical habitat. This was further confirmed by Simpson's Dominance Index value (0.1903), which was very low indicating the disparity in the population of different ladybird species in a community. Pervez and Khan (2019) found high Pielou's evenness Index from Uttarkashi and Chamoli that indicates even distribution of species of ladybird beetles on the hilly terrain of similar geographical habitats. However, similar species were found in Nainital and Almora as revealed by high Sorenson's Index 
(Pervez and Khan, 2019). The ladybird beetles' prey range, host-plant complexes, geographic habitat, the active period of their abundance, the total number of individuals, and the frequency (\%) of the sampled ladybird species from five zoogeographical sites of Uttarakhand have been presented in Table-2. However, their distribution, distinctive characters, prey range, and ecological importance are listed and described below:

\section{Platynaspis saundersi Crotch (Fig.1) \\ Subfamily Chilocorinae \\ Tribe: Platynaspidini}

\section{Distribution:}

India: Kashmir (Khan et al. 2009; Bhat 2017), Himachal Pradesh (Sharma et al. 2017); Uttarakhand (as per present study) - Chamoli

Globally: Afghanistan, Nepal, Pakistan (Hayat etal. 2014); Sri Lanka

Distinctive characters: Appearance is brown in color with thin silky hair and round body. Elytra are hairy with 10 black and asymmetrical spots; pronotum and scutellum black in color; one large spot on mid-dorsal line at the junction of elytra and five spots on each elytron. Its adults were found on apple, pear and wild apple trees. It has been reported as an accidental predator of certain unidentified aphids (Agarwala and Ghosh 1988).

Prey range: unidentified aphids on Solanum nigrum L. (Poorani 2002a; Sharma et al. 2017). unidentified aphids on host plants, viz. Holoptelea integrifolia (Roxb.), Toona ciliata M. Roem, Mallotus philippensis Muell., Pongamia pinnata L. and Bauhinia variegata L. from Uttarakhand (Mishra and Yousuf, 2019).

Ecological importance: The adults were found preying on unidentified aphids that attack apple, pear, wild apple trees (Khan et al. 2009). These are more prevalent in forest areas.

\section{Scymnus posticalis Sicard, 1913 (Fig.2) \\ Subfamily - Scymninae \\ Tribe - Scymnini}

Distribution: India: Kashmir (Bhat 2017); Uttarakhand (as per present study) - Almora, Chamoli, Nainital (First report in Uttarakhand).
Globally: China, Myanmar; Japan (Agarwala and Yasuda 2001)

Distinctive characters: Small and oval body, highly convex; short antennae; head brownish black, not clearly visible from above and eyes small and brownish- black; pronotum black and apomorphic and densely pubescent pushing scutellum posteriorly; scutellum black; elytra shiny black throughout except at the anal region where it is light reddish-brown. The head has an arched frons large eye with inner orbits usually fine. Larvae have simple setose processes and are typically covered in waxy exudations.

Prey range: Tetranychus odinae (Van de Goot), Aphis craccivora (Koch), Aphis gossypii (Glover) (newly found prey as per present study), and scale insects (Ashfaque et al. 2015).

Host plants/trees: Fruit trees like apples, walnut and grapes (Ashfaque et al. 2015), Maize, cucumber, colocasia, sorghum, and citrus (Sharma et al. 2017)

Ecological importance: It could be used for biocontrol of mites. Their pupae possess defensive traits, as they keep their final-instar larval exuviae and secrete defensive chemical droplets at the tips of glandular hairs, which protect them from predators (Mizuno et al. 2017).

Active period: Usually active in August to March in general. However, we found adults from September to November preying on A. gossypii.

\section{Aiolocaria (=Alloneda) hexaspilota (Hope) Barovsky, 1928: 232 (Fig. 3) \\ Subfamily - Coccinellinae \\ Tribe - Coccinellini}

\section{Distribution:}

India: Kashmir (Khan et al. 2009); Uttarakhand (as per present study)-Uttarkashi

Globally: Pakistan (Rafi et al. 2005; Khan et al., 2007; Hayat et al. 2017); Nepal (Canepari 1997); China (Shunxiang et al. 2009; Wu et al. 2011); Russia (Kuznetsov, 1997), Japan, Korea, Taiwan, Burma (Hayat et al. 2017).

Distinctive characters: Body slightly convex or broadly oval measuring $8.5 \mathrm{~mm}$ to $12.2 \mathrm{~mm}$, little longer than wide; black pronotum with apple yellow spots on sides, round angles, deep 
depressions at the anterior margins; orange-red elytra with black bands only or black bands with red or orange spots at sides; epipleura very broad.

Prey range: The main prey species is Gastrolina depressa Baly (Kuznetsov 1997), Scale insects (Khan et al. 2009), Quadraspidiotus perniciosus Comstock (Irshad 2001) in Pakistan.

Host plants/trees: It was found feeding on unidentified aphids on Juglans manshurica Maxim and Quercus leucotrichophora A. Camus tree in Uttarakhand (Mishra and Yousuf, 2019).

Ecological importance: Found in apple orchards and walnut attacking scale-insects.

Active period: Its life-stages occur more in number in July and we found adults during September and October preying on A. gossypii.

4. Aiolocaria dodecaspiolota (Hope) (Fig. 4) Crotch, 1874:178.-Korschefsky, 1932: 277 (cat.)

Subfamily - Coccinellinae

Tribe - Coccinellini

Distribution:

India: Uttarakhand (as per present study) Uttarkashi. This is the first report from Uttarakhand.

Globally: Northern Pakistan (Irshad 2001) and Nepal (Canepari 1997).

Prey range: Aphids, Rhopalosiphum maidis (Fitch) (Agarwala and Ghosh 1988) and Taoia indica (Ghosh and Raychaudhuri).

Ecological importance: Found feeding on $Q$. perniciosus (Irshad 2001), scale insects on walnut and other vegetation.

Active period: We found it active in September and October.

\section{Calvia albida (Biewlawski) (Fig. 5)}

Subfamily - Coccinellinae

Tribe - Coccinellini

Distribution: Distributed throughout the Palaearctic and Oriental regions.

India: Uttarakhand- Chamoli; Uttarkashi (as per the present study). This is the first report from Uttarakhand.

Globally: China (Wu et al. 2011)
Distinctive characters: Male broadly oval, dorsum convex, broadest a little before the middle of elytra, elytra nearly as wide as long; glabrous except head with silvery-white hairs. Dorsum bright lemon yellow to yellowish, pronotum with an indistinct M-shaped marking. Antennae 11segmented, elongate. Female genitalia lacks infundibulum.

Prey range: Mollitrichosiphum alni Ghosh et al., Vesiculaphis sp., A. gossypii, A. craccivora, Acyrthosiphon pisum (Harris) (Omkar and Pervez 2004).

Ecological importance: They are generally predators of aphids and psyllids on variety of trees and shrubs.

Active period: We found adults preying on $A$. craccivora during September and October.

\section{Menochilus (Cheilomenes) sexmaculatus (Fabricius 1801/1781) (Fig. 6) \\ Subfamily - Coccinellinae \\ Tribe - Coccinellini}

Distribution: It is the most frequent, rich and widely distributed species throughout the Oriental region.

India: Uttarakhand - Almora, Chamoli, Nainital, Udham Singh Nagar, Uttarkashi (in the present study), Haridwar and Dehradun (Joshi and Sharma, 2008).

Globally: Afghanistan, Indonesia, USSR, Bangladesh; Pakistan (Ahmed et al. 2017); China (Wu et al. 2011)

Distinctive characters: Body size varies from $5.4 \times 6.3 \mathrm{~mm}$ to $5.5 \times 6.2 \mathrm{~mm}$; Body oval or nearly round, little bit convex and glossy; Body color varies from yellow, orange, pink to slightly red; Head yellow-brown and concealed in pronotum; T-shaped median band on anterior pronotum, linked to a broad band on posterior pronotum margin; Scutellum brownish-black; Six black patches of varying shapes on elytra including two zig-zag black lines and a black spot on the posterior end; Broad black line along the junction of elytra with scutellum, longitudinally; The patches on elytra vary with V-shaped on the first pair, W-shaped on the second pair and somewhat round on the third pair of elytra. 
Prey range: Highly aphidophagous (Omkar and Pervez 2004), Feeds on Adelgids sp., whitefly Bemisia tabaci (Gennadius) and Pyrilla perpusillai Walker (Rahatullah et al. 2011), psyllids and mites; tea aphid Toxoptera aurantii Boyer (Roy and Rahman 2014)

Host plants: Helianthus annuиs L. and Zea mays L. and tea plant Camellia sinensis (L.)

Ecological importance: Found commonly in plain areas and occasionally in foot hills; Brassica and maize crops.

Active period: Adults are active during April and July-August in Pakistan (Rahatullah et al. 2011). However, we found all life stages, viz. eggs, larvae, pupae and adults during September to December, and then in February.

\section{Coccinella septempunctata (Linnaeus 1758)} by subsequent designation of Latreille, 1810: 432. (Fig. 7)

\author{
Subfamily - Coccinellinae \\ Tribe - Coccinellini
}

Distribution: It is one of the most common and widely studied ladybird beetles, reported from India as well as different parts of the world.

India - Kashmir (Khan et al. 2009; Bhat 2017); Himachal Pradesh (Sharma et al. 2017); Uttarakhand- Almora, Chamoli, Nainital, Udham Singh Nagar, Uttarkashi (as per present study), Haridwar and Dehradun (Joshi and Sharma 2008).

Globally: Asia, Europe, North America and South America, Pakistan (Rahatullah et al. 2011); China (Wu et al. 2011)

Distinctive characters: Body size ranges from $7.9 \times 6.8 \mathrm{~mm}$ to $8 \times 6.9 \mathrm{~mm}$.

Polymorphic forms. Body oval, convex (say hemispherical), densely punctate; Seven black spots of variable sizes, three on each elytron and one just behind the middle of the thorax, Patchy black elytra with no hair but finely pitted; Black head, pair of yellow spots on the frons near eyes; Pronotum twice broad as long, black and densely pitted; Scutellum black or brownish-black and almost equilateral; Antennae 11-segmented.

Prey range: Feeds on a variety of aphids viz., Aphis pomi De Geer, Lipaphis erysimi (Kaltenbach), Myzus persicae (Sulzer),
Brevicoryne brassicae (L.), and other aphids in Kashmir (Khan et al. 2009); A. craccivora, Aphis fabae, Scopoli and A. gossypii in Pakistan (Rahatullah et al. 2011). Besides it also feeds on mealybugs and psyllids and scale insects.

Ecological importance: Present in all types of habitats and agro-ecosystems, viz. wheat brassica, cabbage, cotton, fruit trees and cruciferous crops in Kashmir (Khan et al. 2009). It is a major biocontrol agent of mustard aphid, L. erysimi. -

Host plants/trees: Z. mays, S. melongena, Lectuca sativa L., Triticum aestivum L., Morus alba L. and Brassica compestris L. in Pakistan (Rahatullah et al. 2011).

Active period: May-July in Kashmir (Khan et al. 2009); May-September in Pakistan (Rahatullah et al. 2011), and September to December and then February in Uttarakhand.

\section{Coccinella transversalis (Fabricius) (Fig. 8)}

Subfamily - Coccinellinae

Tribe - Coccinellini

\section{Distribution:}

India: Uttarakhand (Mishra and Yousuf, 2019) Almora, Chamoli, Nainital, Udham Singh Nagar, Uttarkashi (as per the present study), Nainital (Joshi et al., 2012), and Haridwar (Joshi and Sharma, 2008).

Globally: Pakistan (Rahatullah et al. 2011; Hayat et al. 2017); Sri Lanka (Poorani, 2004; Mayadunnage et al. 2007); Australia, Bangladesh, China, Indonesia, Japan, Nepal, New Zealand (Poorani 2002b)

Distinctive characters: Adult is $5 \mathrm{~mm}$ long; Slightly elongate body; pronotum with orange spots on anterio-lateral side; dull orange elytra, yellowish-brown indistinct spots; on each elytron, the first patch is irregular and small, the second patch is large and third is a round spot; there is a longitudinal black broad band along the inner junction of elytra.

Prey range: Aphids- A. craccivora, A. fabae, A. gossypii, M. persicae, leaf and plant hoppers Amrasca spp, Empoasca vitis Gothe and Leptocentrus spp (Mayadunnage et al. 2007).

Host plants/trees: Glycine max (L.) Merr., $L$. sativa, Hibiscus esculentus L. and Prunus 
domestica L. and H. annuus (Rahatullah et al. 2011); agricultural fields, L. purpureus , S.nigrum (Omkar and Pervez 2004), forest trees, Populus deltoides W. Bartram, Dillenia indica L., Elaeocarpus ganitrus Roxb., Eucalyptus sp. and Alstonia scholaris (L.) R. Br. (Mishra and Yousuf, 2019).

Ecological importance: It is the second major invader of various ecosystems and biogeographical habitats after C. septempunctata and is also as intraguild predator in the guild.

Active period: April-October is the active period reported by Hayat et al. (2017) and the larvae and adults are highly active during September to December, and February in the present study.

\section{Harmonia eucharis (Mulsant) Iablokoff-} Khnzorian, 1979: 71; 1982 (rev.).-Singh \& Phaloura, 1990: 89 (field key to larva) (Fig. 9)

Subfamily - Coccinellinae

Tribe - Coccinellini

\section{Distribution:}

India: Himachal Pradesh (Sharma et al. 2017); Kashmir (Khan et al. 2009); Uttarakhand Chamoli, Uttarkashi (as per present study)

Globally: Pakistan (Rafi et al. 2005; Hayat et al. 2017); Southern China (Poorani 2004); China (Wu et al. 2011); Myanmar, Nepal

Distinctive characters: Length up to 3 to $7 \mathrm{~mm}$; the colour of elytra is usually red to orange with black spots; the patches can be linked together to form black bars; hemispherical creamy grey body with yellow tinge; yellowish-grey pronotum with pale brownish markings; variable spots on elytra, spots may be distinct, indistinct or fused to form bands

Prey range: Aphids, A. pomi, Cervaphis rappardi indica Basu, Hyalopterus pruni (Geoffrey), M. persicae, Myzus varians Davidson, Phorodon cannabis Passerini, Bradycaudus helichrysi Kaltenbach and Eriosoma lanigerum (Hausmann) (Omkar and Pervez 2004).

Host plants/trees: coriander, wheat (Hayat et al. 2017); Fruit trees, Euonymus trees, blue pine trees and forest trees (Khan et al. 2009); Peaches, apple, conifers (Sharma et al. 2017)
Ecological importance: $H$. eucharis was collected from fruit trees and forest trees of study sites. It is also known to shift its host as just before the start of autumn, it is found on pine trees in abundance and migrates to fruit trees in summer.

Active period: April-July is the active period reported by Hayat et al. (2017), however we found adults during September to October.

\section{Harmonia sedecimnotata (Fabricius 1801)} (Fig. 10)

Subfamily - Coccinellinae

Tribe - Coccinellini

\section{Distribution:}

India: Uttarakhand - Chamoli, Uttarkashi (as per the present study). This is the first report from Uttarakhand.

Globally: Russia (Reznik and Vaghina, 2006); China (Wu et al. 2011)

Distinctive characters: The color of the elytra is frequently red to orange with black spots. The patches can be linked together to form black bars. The species can reach a length of 3 to $8 \mathrm{~mm}$. The rear edge of the pronotum is slightly curved.

Prey range: $M$. persicae (Reznik and Vaghina 2006), and M . alni (Omkar and Pervez 2004).

Host plants/trees: Vicia faba L. (Reznik and Vaghina 2006)

Ecological importance: Rare indigenous species, which seemingly is a specialist predator of aphids.

Active period: April-July is the active period reported by Hayat et al. (2017) and the adults are highly active from September to October in the present study.

\section{Hippodamia variegata (Goeze, 1777) (Fig. 11)}

Subfamily - Coccinellinae

Tribe - Coccinellini

\section{Distribution:}

India: Himachal Pradesh (Sharma et al. 2017); Kashmir (Bhat 2017); Uttarakhand (Joshi and Sharma 2008); Uttarakhand (Mishra and Yousuf, 2019) - Almora, Chamoli, Uttarkashi (as per present study), Nainital (Joshi et al., 2012), and Haridwar (Joshi and Sharma, 2008). 
Globally: Asia (Zare et al. 2013), Europe; Pakistan (Rahatullah et al. 2011; Hayat et al. 2017); China (Shunxiang et al. 2009); Tibet (Poorani 2004); Afghanistan, Mongolia, Northern and eastern Africa.

Distinctive characters: Body size ranges from $5.1 \times 3.3 \mathrm{~mm}$ to $6.3 \times 3.3 \mathrm{~mm}$; Creamy red colored and oval body; Brown head with black and white pattern behind it; Distinctive black eyes and black spots on the red forewings; Several polymorphs with varying elytral spots (few to 13), generally six spots with one prominent spot on the middorsal line joining elytra with scutellum; Yelloworange elytra with brownish spots, no hair; Pronotum yellow-white with brown-black areas at the posterior margin and four finger-like thick anterior projections. $1.3 \mathrm{~mm}$ long and 11segmented antennae; 3-segmented labial palpi (Kuznetsov, 1997).

Prey range: It feeds on A. pomi, $M$. persicae, $A$. fabae, B. brassicae, A. craccivora and some mites (Khan et al. 2009); Aphis citricola van der Goot, and A. gossypii, (Omkar and Pervez, 2004).

Host plants: $T$. aestivum, $B$. campestris, Medicago sativa and Z. mays in Kashmir (Khan et al. 2009); T. aestivum, B. campestris and Coriandrum sativum L. in Pakistan (Rahatullah et al. 2011); apple walnut, mulberry, fig-trees, wheat, cabbage, wild plants (Hayat et al. 2017). Dalbergia sissoo Roxb., Shorea robusta C. F. Gaertn. and Tectona grandis L. (Mishra and Yousuf, 2019).

Ecological importance: Found in fodders, crops, and wild vegetation. It is an important predator of the cotton aphid, A. gossypii.

Active period: It is active in May-June in Kashmir and February-May in other parts of northern India (Khan et al. 2009) and is found abundantly in February in Uttarakhand.

\section{Illeis cincta (Fabricius) (Fig. 12)}

Subfamily - Coccinellinae

Tribe - Coccinellini

\section{Distribution:}

India: Uttarakhand - Chamoli, Udham Singh Nagar (as per present study) and Haridwar (Joshi and Sharma, 2008).
Globally: Sri Lanka (Mayadunnage et al. 2007); Indonesia (Poorani, 2002b).

Distinctive characters: Adult is $5.2-6.0 \mathrm{~mm}$ long and $4.0-4.5 \mathrm{~mm}$ broad across the middle elytra. Head is yellowish with a pair of prominent black eyes. Two spots are situated on the dorsolateral aspects of posterior margin of the thorax.

Prey range: It actively feeds upon red spider mite, Tetranychus sp., A. craccivora, M. persicae, A. gossypii, Aphis nerii Boy., R. maidis, Amrasca devastans (Distant) (Mayadunnage et al. 2007)

Host plants/trees: Cucumber, rose (Sharma et al. 2017)

Ecological importance: It is primarily a mycophagous ladybird but occasionally may feed on aphids also.

Active period: We found the adults in September and October.

\section{Illeis confusa (Fabricius) Timberlake, 1943 (Fig. 13)}

Subfamily - Coccinellinae

Tribe - Coccinellini

\section{Distribution:}

India: Uttarakhand - Almora, Chamoli, Udham Singh Nagar (as per present study)

Globally: Pakistan (Rafi et al. 2005; Rahatullah et al. 2011; Hayat et al. 2017); Thailand; Nepal, China (Poorani 2004).

Distinctive characters: Medium-sized, oval and slightly convex body; creamy pronotum with two black spots at centre; creamy elytra without spots Prey range: Aphids (Rahatullah et al. 2011).

Host plants/trees: D. sisso and some ornamental plant in Pakistan (Rahatullah et al. 2011); sheesham (Hayat et al. 2017); peaches and light traps (Sharma et al. 2017). It is primarily a mycophagous ladybird but occasionally may feed on aphids.

Active period: We found the adults in the months of September and October. However, it was also reported active in the months of SeptemberOctober in Pakistan (Rahatullah et al. 2011) and August to October by Hayat et al. (2017). 
14. Micraspis discolor (Fabricius, 1798) (Fig. 14)

Subfamily - Coccinellinae

Tribe - Coccinellini

Distribution: India: North-east India (Roy and Rahman, 2014); Andhra Pradesh (Shanker et al. 2013); Uttarakhand - Almora, Chamoli, Nainital, Udham Singh Nagar, Uttarkashi (as per present study), Nainital (Joshi et al., 2012), and Haridwar (Joshi and Sharma, 2008).

Globally: China (Wu et al. 2011); Bangladesh (Begum et al. 2002; Chowdhury et al. 2008); Thailand (Rattanapun, 2012); Sri Lanka (Mayadunnage et al. 2007); almost all Oriental and Palaearctic (Poorani, 2002a)

Distinctive characters: Body oval and convex; orange to reddish-orange elytra; male $(3.64 \mathrm{~mm}$ long and $2.82 \mathrm{~mm}$ wide) usually smaller than female (4.08 $\mathrm{mm}$ long and $3.24 \mathrm{~mm}$ wide); elytra is yellowish red with two small rounded black spots on each elytron: one towards the proximal end and the other towards the distal end.

Prey range: brown planthopper, Nilaparvata lugens (Stal), green leafhopper Nephotettix virescens (Distant), white-backed planthopper Sogatella furcifera (Horvath), aphid Rhopalosiphum padi L. and thrip, Haplothrips sp. (Shankar et al. 2013); A. gossypii, and Nephotettix sp. (Rattanapun 2012); T. aurantii (Roy and Rahman 2014); Lepidopteron insects, mealybug, white flies (Mani, 1995); A. gossypii, M. persicae, A. craccivora, and leaf hoppers Amrasca spp. (Mayadunnage et al. 2007).

Host plants/trees: rice, tea plant Camellia sinensis (L.); bean, wheat, chili, sorghum, tobacco, cotton, maize, potato, lathyrus, soyabean, sweet potato, lentil, mustard, brinjal, groundnut, sunflower and cabbage (Gautam et al. 1995; Duffieded, 1995).

Ecological importance: It is entomophagous as well as phytophagous (Shankar et al. 2013); primarily cannibalistic (Begum et al. 2002); Pollinivorous (Rattanapun 2012). M. discolor adults feed more on rice with pollen (reproductive stage) over rice without pollen (vegetative stage) and the population abundances of $M$. discolor are not related to the population abundance of hopper insects (Rattanapun 2012)

Active period: It was reported to be active from September to November (Chowdhury et al. 2008) and we found it active from October to November.

\section{Oenopia sauzeti (Mulsant 1846) (Fig. 15) \\ Subfamily - Coccinellinae \\ Tribe - Coccinellini}

\section{Distribution:}

India: Himachal Pradesh (Sharma et al. 2017); Uttarakhand - Almora, Chamoli, Nainital, Uttarkashi (as per the present study), Nainital (Joshi et al., 2012), and Haridwar (Joshi and Sharma, 2008; Sharma and Joshi, 2020).

Globally: Pakistan (Inayatullah et al. 2005; Rahatullah et al. 2011; Hayat et al. 2017); Thailand (Poorani 2004); China (Wu et al. 2011); Nepal, Bhutan, Myanmar

Distinctive characters: Round and strongly convex body; black pronotum with yellow spots, loosely attached with the body; light yellowish to white elytra with brownish-black spots which are large and round; total six spots- two spots on each elytron, two on mid-dorsal line at the junction of the elytra and two central spots are connected by a band

Prey range: A. fabae, A. gossypii, Aphis kurosawaii (Takahashi), Aphis longisetosa Basu, B. brassicae, B. helichrysi, Capitophorus formosartemisiae (Takahashi), Cavariella aegopodii (Scopoli), Clethrobius drobius Chakrabarti and Raychoudhuri, E. lanigerum, A. craccivora, A. fabae and A. gossypii in Pakistan (Rahatullah et al. 2011)

Host plants/trees: Z. mays and an ornamental plant in Pakistan (Rahatullah et al. 2011); Okra, cabbage, Brassica, walnut, fig, wheat (Hayat et al. 2017)

Ecological importance: Largely aphidophagous and may be used for biocontrol of A. gossypii.

Active period: April to October is the active period reported by Hayat et al. (2017) and we found it active during October to November.

\section{Propylea dissecta (Mulsant) (Fig. 16)}

Subfamily - Coccinellinae 
Tribe - Coccinellini

\section{Distribution:}

India: Himachal Pradesh (Sharma et al. 2017); Uttarakhand - Nainital, Udham Singh Nagar (as per present study) and Haridwar (Joshi and Sharma, 2008).

Globally: Nepal (Poorani, 2004) and Pakistan (Inayatullah et al. 2005; Hayat et al. 2017), China, Bangladesh, Sri Lanka (Mayadunnage et al. 2007)

Distinctive characters: Body size 4.8 x $3.5 \mathrm{~mm}$; Body oval, little bit convex and black on ventral side; Head brown with black pronotum and scutellum and short antennae; Tiny eyes, finely facetted; Brown body with four black bands forming a network with two bands on each elytron, one on anterior and one on the posterior side of elytron; Mid-dorsal line indicating junction of elytra with scutellum is black. This species is polymorphic with intermediate and pale forms (Pervez et al. 2004).

Prey range: This species is an important predator of psyllids, whiteflies and aphids, viz. $M$. persicae, A. gossypii, A. craccivora, L. erysimi, $B$. brassicae, A. nerii (Pervez and Omkar 2004; Mayadunnage et al. 2007).

Host plants/trees: Akk plant, custard plant, wheat, okra, walnut, brassica (Hayat et al. 2017), S. melongena, and Brassica oleracea L. (Sharma et al. 2017)

Ecological importance: Less common occurrence in agro-ecosystem. Brassica plants,

Active period: April to October is the active period reported by Hayat et al. (2017) and we found it active during February.

\section{Propylea luteopustulata (Mulsant, 1850)}

(Fig. 17)

Subfamily - Coccinellinae

Tribe - Coccinellini

Distribution:

India: Himachal Pradesh (Sharma et al. 2017); Kashmir (Khan et al. 2009; Bhat 2017); Uttarakhand - Almora, Chamoli, Nainital (as per present study). This is the first report from Uttarakhand.
Globally: Pakistan (Khan et al. 1999; Hayat et al. 2017); Vietnam (Canepari 1997); Bhutan, Nepal, Sri Lanka.

Distinctive characters: Medium-sized body; pronotum pale at the anterior side but black at posterior side; scutellum black and small; elytral anterior margin straight, glabrous and pale yellow, each with five black spots.

Prey range: Aphids viz. A. craccivora, A. gossypii, L. erysimi and B. brassicae, psyllids, and whiteflies (Rahatullah et al. 2011).

Host plants/trees: Fruit orchards; T. aestivum and B. campestris (Rahatullah et al. 2011); walnut trees (Hayat et al. 2017); Apple, radish, peach, eggplant (Sharma et al. 2017)

Ecological importance: An important predator of A. gossypii in North India

Active period: April is the active period reported by Hayat et al. (2017) and we found it active during February.

\section{Palaeoneda auriculata (Mulsant, 1866) (Fig 18) \\ Subfamily - Coccinellinae \\ Tribe - Coccinellini \\ Distribution:}

India: Uttarakhand - Chamoli (as per present study). This is the first report from Uttarakhand.

Globally: Nepal (Poorani, 2004), Pakistan (Khan et al. 1999; Rafi et al., 2005; Hayat et al. 2017), China (Shunxiang et al. 2009)

Distinctive characters: Body oval, large size, shiny ventral surface, slightly convex. Pronotum black, broad spots on both sides which may be white or creamy; orange elytra with no spot, broad epipleura

Host plants/trees: Walnut, Bersem

Prey range: Unidentified aphids

Ecological importance: Threatened species and its numbers are very scarce in North India.

Active period: April to June is the active period reported by Hayat et al. (2017) and we found it active during February. 
J. Mountain Res. P-ISSN: 0974-3030, E-ISSN: 2582-5011

Vol. 15, (2020), 7-20

DOI: https://doi.org/10.51220/jmr.v15il.2

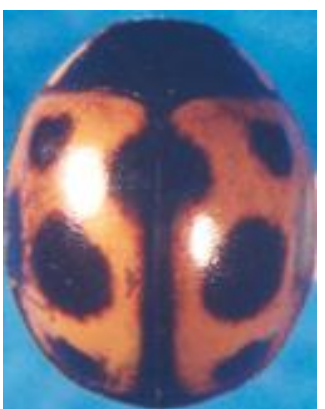

Fig. 1

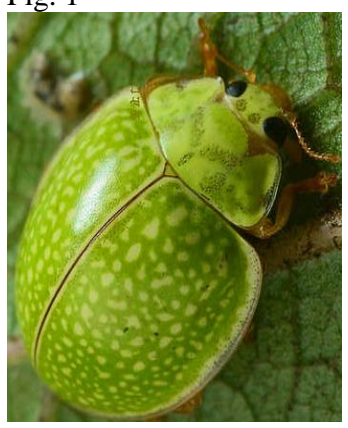

Fig. 5

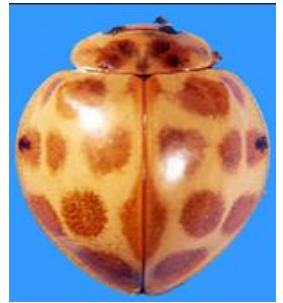

Fig 9
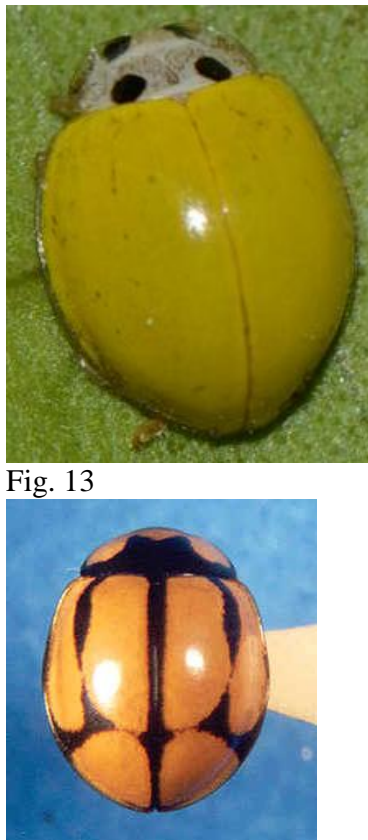

Fig. 17
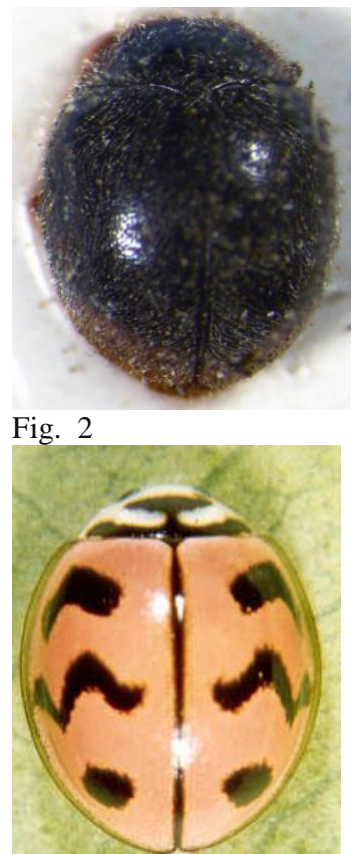

Fig. 6

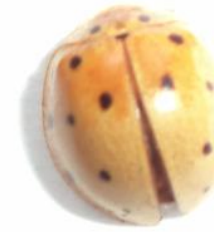

Fig. 10
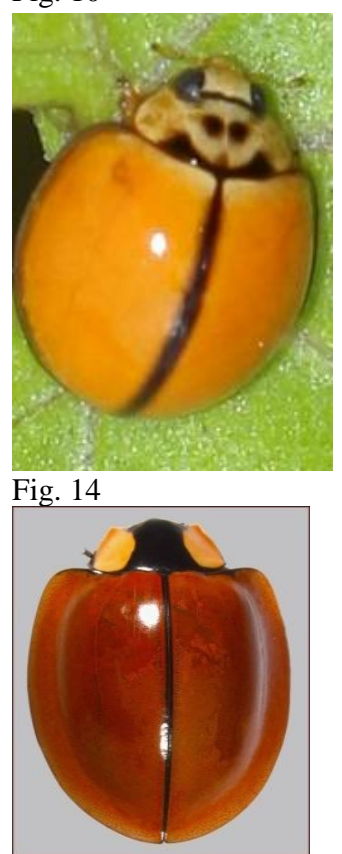

Fig. 18

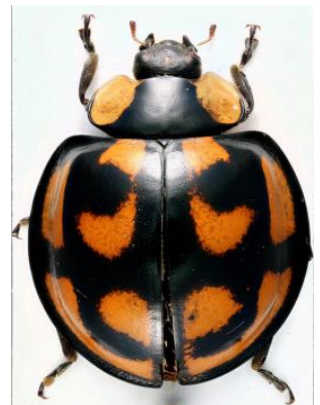

Fig. 3

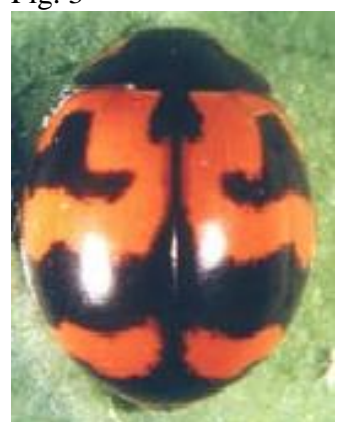

Fig.7

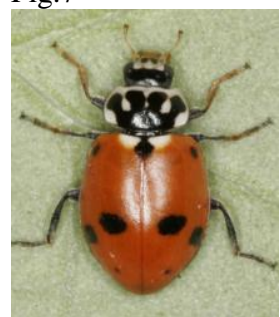

Fig $>11$

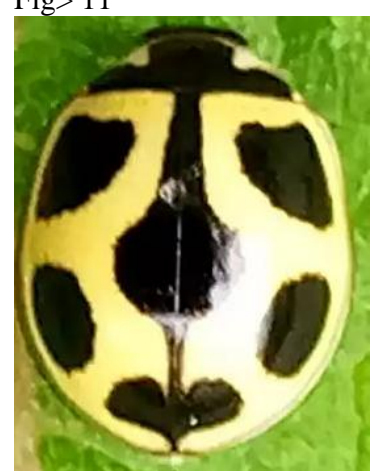

Fig. 15

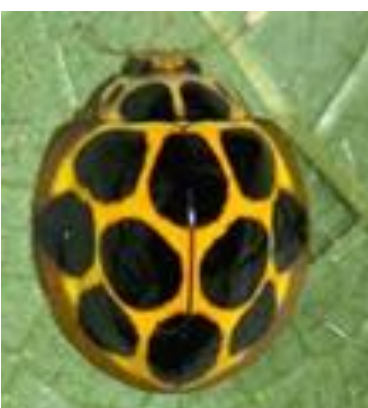

Fig. 4

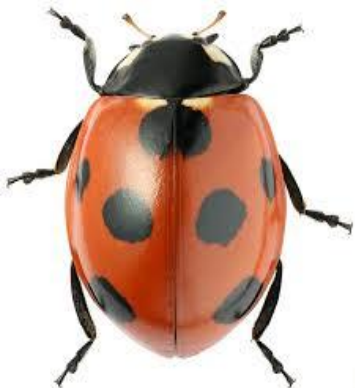

Fig. 8

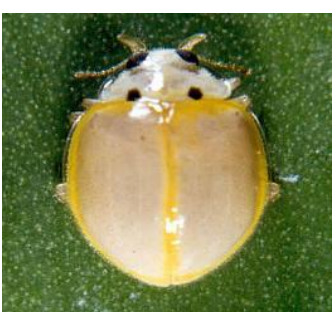

Fig 12

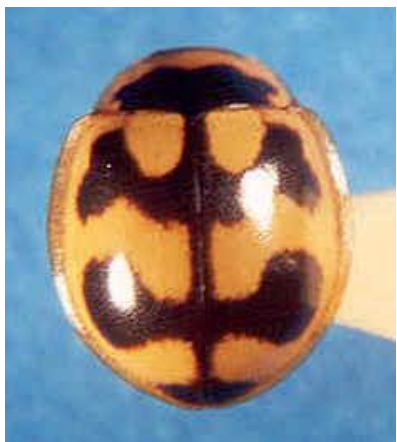

Fig 16

Figures 1-18 : Photographs of ladybirds (1-Platynaspis saundersi, 2-Scymnus posticalis 3-Aiolocaria hexaspilota, 4- Aiolocaria dodecaspiolota, 5- Calvia albida, 6- Menochilus sexmaculatus, 7- Coccinella septempunctata, 8- Coccinella transversalis, 9Harmonia eucharis, 10- Harmonia sedecimnotata, 11- Hippodamia variegata, 12- Illeis cincta, 13- Illeis confusa, 14- Micraspis discolor, 15- Oenopia sauzeti, 16- Propylea dissecta, 17- Propylea luteopustulata, 18- Palaeoneda auriculata). 
J. Mountain Res. P-ISSN: 0974-3030, E-ISSN: 2582-5011

Table 2: Species of ladybird beetles, prey species, host plant(s), place as district habitat, active period, total number of individuals and the frequency (\%) of the sampled ladybird species from five zoo-geographical sites of Uttarakhand.

\begin{tabular}{|c|c|c|c|c|c|c|c|}
\hline S. No. & Ladybird beetle & Prey species & Host plant(s) & Place & Active Period of the year & Number & $\begin{array}{l}\text { Frequency } \\
(\%)\end{array}$ \\
\hline 1. & Platynaspissaundersi & A. craccivora & Lablab purpureus (L.) Sweet & $\mathrm{C}$ & Sept., Oct. & 04 & 0.21 \\
\hline 2. & Scymnusposticalis & A. gossypii & $\begin{array}{l}\text { Lagenaria siceraria (Molino) } \\
\text { Standl }\end{array}$ & $\mathrm{A}, \mathrm{C}, \mathrm{N}$ & Sept., Oct., Nov. & 31 & 1.65 \\
\hline 3. & Aiolocariahexaspilota & A. gossypii & L.siceraria & UT & Sept., Oct. & 10 & 0.53 \\
\hline 4. & Aiolocariadodecaspiolota & A. gossypii & Cucumis sativus L. & UT & Sept., Oct. & 12 & 0.64 \\
\hline 5. & Calvia albida & A. craccivora & L. purpureus & C, UT & Sept., Oct. & 26 & 1.38 \\
\hline 6. & Menochilus sexmaculatus & $\begin{array}{l}\text { A. craccivora } \\
\text { A. nerii }\end{array}$ & $\begin{array}{l}\text { L. purpureus } \\
\text { Calotropis procera(Aiton) }\end{array}$ & $\begin{array}{l}\text { A, C, N, UT, } \\
\text { US }\end{array}$ & Sept.,Oct.,Nov.,Dec., Feb & 446 & 23.69 \\
\hline 7. & Coccinellaseptempunctata & L. erysimi & B. campestris & $\begin{array}{l}\text { A, C, N, UT, } \\
\text { US }\end{array}$ & $\begin{array}{l}\text { Sept., Oct., Nov., Dec., } \\
\text { Feb. }\end{array}$ & 605 & 32.13 \\
\hline 8. & Coccinella transversalis & L. erysimi & B. oleracea & $\begin{array}{l}\text { A, C, N, UT, } \\
\text { US }\end{array}$ & $\begin{array}{l}\text { Sept., Oct., Nov., Dec., } \\
\text { Feb. }\end{array}$ & 212 & 11.26 \\
\hline 9. & Harmonia eucharis & L. erysimi & B. campestris & C, UT & Sept., Oct. & 56 & 2.97 \\
\hline 10. & Harmonia sedecimnotata & A. gossypii & L.siceraria & C, UT & Sept., Oct. & 36 & 1.91 \\
\hline 11. & Hippodamia variegata & A. craccivora & $\begin{array}{l}\text { L. purpureus, Phaseolus } \\
\text { vulgarisL. }\end{array}$ & $\mathrm{A}, \mathrm{C}, \mathrm{UT}$ & Sept., Oct. & 213 & 11.31 \\
\hline 12. & Illeiscincta & A. gossypii & L.siceraria & $\mathrm{C}, \mathrm{US}$ & Sept., Oct. & 14 & 0.74 \\
\hline 13. & Illeisconfusa & A.gossypii & C. sativus & A, C, US & Sept., Oct. & 10 & 0.53 \\
\hline 14. & Micraspis discolor & A. craccivora & L. purpureus, P. vulgaris & $\mathrm{A}, \mathrm{C}, \mathrm{US}$ & Oct., Nov. & 76 & 4.04 \\
\hline 15. & Oenopiasauzeti & A. craccivora & L. purpureus, P. vulgaris & $\mathrm{A}, \mathrm{C}, \mathrm{US}$ & Oct., Nov. & 24 & 1.27 \\
\hline 16. & Propylea dissecta & A. craccivora & L. purpureus, P. vulgaris & US & Feb. & 78 & 4.14 \\
\hline 17. & Propylea luteopustulata & A.gossypii & C. sativus & US & Feb. & 22 & 1.17 \\
\hline 18. & Palaeoneda auriculata & B. brassicae & B. oleracea & US & Feb. & 08 & 0.42 \\
\hline \multicolumn{6}{|c|}{ Simpson's Dominance Index $(C)=0.1903$} & $\begin{array}{l}t=2.39 \\
P<0.05\end{array}$ & $\begin{array}{l}\mathbf{t}=2.17 \\
\mathbf{P}<0.05\end{array}$ \\
\hline
\end{tabular}




\section{Conclusion}

The present study was an attempt to describe the predaceous coccinellid fauna of the Uttarakhand region. The object of this study was to explore, identify, and prepare an inventory of coccinellid species in this region, which will be helpful for future researchers working on ladybirds. Six species are first reports from this region. Uttarakhand also provides station to the coccinellid species migrating from higher mountainous altitudes of Himalayas during winters to settle down in a warmer and much lower altitude. This is a major reason for the increase in new biodiversity in this region. A disparity was found in the ladybird-abundance as few species, viz. C. septempunctata, $M$. sexmaculatus, $C$. transversalis, and $H$. variegata dominated in numbers over other species. We only explored five zoogeographical habitats from Uttarakhand and still there is much more to be explored. Uttarakhand is a small state with diversified zoogeographical habitats in terms of altitude. Hence, the current record covers only a fraction of coccinellid diversity from this state. More surveys are needed to find out unexplored areas of coccinellid diversity from this state.

\section{Acknowledgements}

We thank Dr. J Poorani, Principal Scientist, Indian Council of Agricultural Research, and India for the identification of certain coccinellids. AP thanks the Science and Engineering Research Board, Department of Science and Technology, Government of India for financial assistance in the form of a Major Research Project (EMR/2016/006296).

\section{References}

Agarwala BK and Ghosh AK (1988) Prey records of aphidophagous Coccinellidae in India. A review and bibliography. Trop. Pest Manag. 34(1): 18-22.

Agarwala BK and Yasuda H (2001) Larval interaction in aphidophagous predators: effectiveness of wax cover as shields of
Scymnus larvae against predation from syrphids. Entomol. Exp. Appl. 100: 101-107.

Ahmed KS, Majeed MZ, Muhammad R, Fatima S and Afzal M (2017). Biodiversity and Species Distribution of Coccinellids (Coccinellidae: Coleoptera) in District Sargodha (Punjab), Pakistan. Pak. J. Zool. 49. 10.17582/journal.pjz/ 2017.49.5.1749.1759.

Ashfaque M, Ullah F, Rafi MA and Naz F (2015) Taxonomic study of subfamily Scyminae (Coleoptera: Coccinellidae) with one new record from Gilgit-Baltistan, Pakistan. Turk. J. Zool. 39: 1034-1040.

Begum MA, Jahan M, Bari MN, Hossain MM and Afsana M (2002) Potentiality of Micraspis discolor (F.) as a biocontrol agent of Nilaparvata lugens (Stal). OnLine J. Biolog. Sci. 2(9): 630-632.

Bhat DM (2017) Host range and diversity of coccinellid (Coleoptera) predators of aphid pests in vegetable crop ecosystems of Kashmir, with new host aphid/plant records. J. Ent. Res. 41(2): 183-186.

Bouchard P, Bousquet $\mathrm{Y}$, Davies AE, AlonsoZarazaga MA, Lawrence JF, Lyal C, Newton AF, Reid C, Schmitt M, Slipinski S and Smith A (2011) Family-group names in Coleoptera (Insecta). Zoo Keys 88: 1-972.

Canepari C (1997) Coccinellidae (Coleoptera) from the Nepal Himalayas. Stuttgarter Beiträge zur Naturkunde, Serie A (Biologie) 565: 1-65.

Chowdhury SP, Ahad MA, Amin MR and Hasan MS (2008). Biology of ladybird beetle Micraspis discolor (Fab.) (Coccinellidae: Coleoptera). Int. J. Sustain. Crop Prod. 3(3): 39-44.

Duffieded SJ (1995) Corp-specific difference in the seasonal abundance of four major predatory groups on sorghum and shortduration pigeon pea. Intl. Chikpea and Pigeon pea Newsl. 2: 74-76.

Gautam RD, Chander S, Sharma VK and Singh R (1995) Aphids infesting safflower, their predatory complex and effect on oil content. Ann. Plant Prot. Sci. 3: 27-30. 
Hayat A, Khan MR and Naz F (2017) Subfamilies Coccinellinae and Coccidullinae (Coccinellidae: Coleoptera) with New Records from AJK, Pakistan. J. Appl. Environ. Biol. Sci. 7(4): 12 -66.

Hayat A, Khan MR, Naz F and Rafi MA (2014) Ladybird beetles of sub-family Chilocorinae (Coccinellidae: Coleoptera of Azad Jammu and Kashmir). Pak. Entomol. 36(2): 135-143.

Inayatullah M, Hayat A and Rafi MA. 2005. Species composition, distribution and seasonal occurrence of Coccinellidae (Coleoptera) in District Poonch, Azad Kashmir with new records. Sarhad J. Agric. 21(1): 97-100.

Irshad M (2001) Distribution, host, ecology and biotic potential of coccinellids of Pakistan. Pak J Biol Sci. 4: 1259-1263.

Joshi PC and Sharma PK (2008) First records of Coccinellid beetles (Coccinellidae) from Haridwar. Nat. Hist. J. Chulalongkon Univ. 8(2): 157-167.

Joshi PC, Khamashon L, Kaushal BR and Kumar $K$ (2012) New additions of coccinellid beetles (Coleoptera: Coccinellidae) to the already reported species from Uttarakhand, India. Nat Sci. 10(6): 26- 30.

Joshi S, Mohanraj P, Rabindra RJ and Rao NS (2003) Production and use of coccinellid predators. Technical Bulletin No. 32, Proj. Director. Biol. Cont., Bangalore, India.

Khan AA, Zaki FA, Khan ZH and Mir RA (2009). Biodiversity of predaceous ladybird beetles (Coleoptera: Coccinellidae) in Kashmir. $J$. Biol. Cont. 23(1): 43-47.

Khan I, Din S, Khalil SK and Rafi MA (2007) Survey of predatory coccinellids (Coleoptera: Coccinellidae) in the Chitral District, Pakistan. J. Insect Sci. 7(7): 1-6.

Kuznetsov VN (1997) Lady beetles of the Russian Far East. Memoir No. 1, Center for Systematic Entomology, The Sandhill Crane Press, Gainesville, 248 pages.

Mani M (1995). Studies of natural enemies of wax scale Drepanococcus chiton (Green) on ber and guava. Entomol. 20: 55-58.
Mayadunnage S, Wijayagunasekara HNP, Hemachandra KS and Nugaliyadde L (2007) Predatory Coccinellids (Coleoptera: Coccinellidae) of vegetable insect pests: A survey in mid country of Sri Lanka. Trop. Agric. Res. 19: 69-77.

Mishra AK and Yousuf M (2019). Notes on coccinellid beetles (Coleoptera: Coccinellidae) from forest ecosystem of Uttarakhand, India. J. Biol. Cont. 33(1): 1-6.

Mizuno T, Hayashi $M$ and Akino $T$ (2017) Combined use of two defensive traits in pupae of Scymnus posticalis ladybirds. Ethology 124: 468-474.

O'Neill KM, Larson DP and Kemp WP (2003). Sweep sampling technique affects estimates of the relative abundance and community composition of grasshoppers (Orthoptera: Acrididae). J. Agric. Urban Entomol.19(3):125-131.

Omkar and Pervez A (2004) Predaceous Coccinellids in India: Predator-prey catalogue (Coleoptera: Coccinellidae). Oriental Insects 38: 27-61.

Omkar and Pervez A (2016) Ladybird Beetles. In: Omkar (edited), Ecofriendly Pest Management for Food Security. Academic Press, Chapter 9; p. 281-310.

Pervez A and Khan M (2019) Biodiversity indices and distribution of predaceous Coccinellidae (Coleoptera) of Uttarakhand, North India. Biodiversity Journal 10: 177-184.

Pervez A and Omkar (2004) Prey dependent life attributes of an aphidophagous ladybird beetle, Propylea dissecta (Mulsant). Biocont Sci Technol. 14: 385-396.

Pervez A, Omkar and Harsur MM (2020) Coccinellids on Crops: Nature's Gift for Farmers. In: Chakravarty AK (edited), Innovative Pest Management Approaches for the 21st Century: Harnessing Automated Unmanned Technologies. Springer International Publisher, Singapore. p. 429460.

Pervez A, Omkar and Richmond AS (2004) The influence of age on reproductive performance 
of the predatory ladybird beetle, Propylea dissecta. J. Insect Sci. 4(22): 1-8.

Poorani J (2002a) A review of the genus Oenopia Mulsant (Coleoptera: Coccinellidae) of the Indian subcontinent with description of a new species. Oriental Insects 36: 97-116.

Poorani J (2002b) An annotated checklist of the Coccinellidae (Coleoptera) (excluding Epilachninae) of the Indian subregion. Oriental Insects 36: 307-383.

Poorani J (2004) Notes on the Coccinellidae (Coleoptera) of the Indian sub-continent, including new synonymies. J. Biol. Cont. 18(2): 185-187.

Rafi AM, Irshad M and Inaytullah M (2005) Predatory Ladybird beetles of Pakistan. Rohani Art Press, Blue Area, Islamabad, Pakistan. 105 pages.

Rahatullah FH, Mehmood SA, Saeed K and Rehman S (2011) Diversity and distribution of ladybird beetles in District Dir Lower, Pakistan. Int. J. Biodiversity Conserv. 3(12): 670-675.

Rattanapun W (2012) Biology and potentiality in biological control of Micraspis discolor (Fabricius) (Coleoptera: Coccinellidae. Commun. Agric. Appl. Biol. Sci. 77(4): 541548.

Reznik SY and Vaghina NP (2006) Dynamics of Fat Content during Induction and Termination of "Trophic Diapause" in Harmonia sedecimnotata Fabr. females (Coleoptera, Coccinellidae). Ent. Rev. 86(2): 125-132.

Roy S and Rahman A (2014) A study on the comparative predatory efficiency and development of Micraspis discolor (F.) and Menochilus sexmaculatus (F.) on tea aphid Toxoptera aurantii (Boyer de Fons.). Zool. Ecol. 24(3): 285-287.

Shankar C, Mohan M, Sampathkumar M, Lydia C and Katti G (2013) Functional significance of Micraspis discolor (F.) (Coccinellidae: Coleoptera) in rice ecosystem. J. Appl. Ent. 137(8): 601-609.

Sharma PK and Joshi PC (2010). New records of coccinellid beetles (Coccinellidae:
Coleoptera) from district Dehradun (Uttarakhand), India. NY. Sci. J. 3: 112-120.

Sharma PK and Joshi PC (2020). Morphological and Taxonomical Descriptions of Oenopia sauzeti (Mul.) and Oenopia kirbyi (Mul.) (Coleoptera: Coccinellidae) reported from district Dehradun Uttarakhand, India. $J$. Env.Bio-Sci. 34(1): 29-32.

Sharma PL, Verma SC, Chandel RS, Chandel RPS and Thakur P (2017) An inventory of the predatory Coccinellidae of Himachal Pradesh, India. J Ent Zool Studies 5: 25032507.

Shunxiang R, Xingmen X, Hong P, Zhengqiang P and Tao Z (2009) Colored pictorial handbook of ladybird beetles in China. Science Press No.16. North Street, City DongHuang, Beijing China, p. 336.

Wu W, Liu D, Zhang P and Zhang Z (2011) Community Structure and Diversity of Ladybugs in Baihualing of Gaoligong Mountain I. Plant Diseases and Pests 2(4): $46-48$.

Zare KM, Biranvand A and Shakarami J (2013) The faunistic survey of lady beetles (Coleoptera, Coccinellidae) in the Mehriz region (Yazd province), Iran Bull. Iraq Nat. Hist. Mus. 12: 43-51.

$* * * * * * * * *$ 